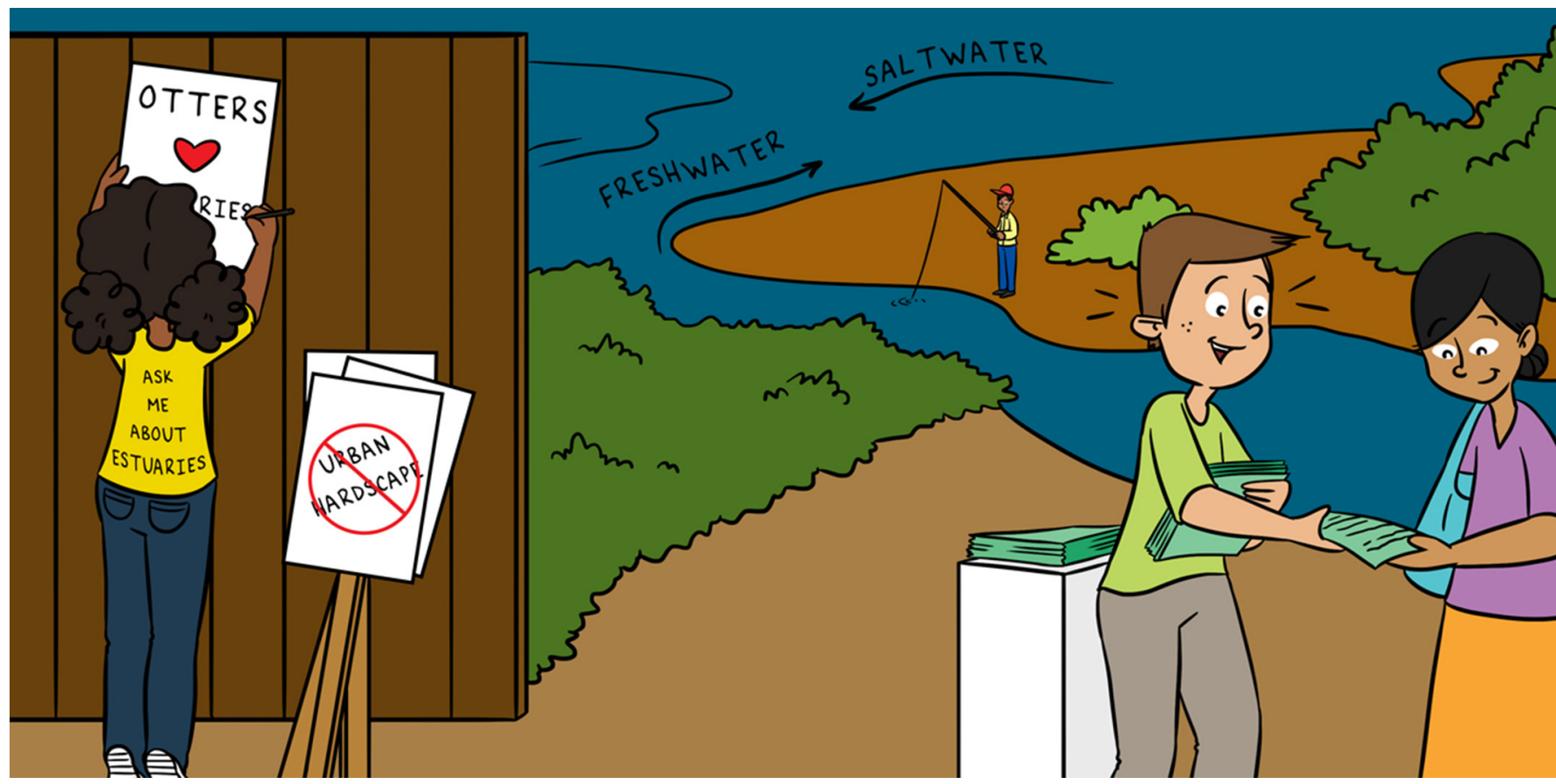

\title{
ESTUARIES, HUMAN BEINGS, AND THE FUTURE
}

\section{Steven D. Culberson *}

Interagency Ecological Program, c/o Delta Stewardship Council, Sacramento, CA, United States

YOUNG REVIEWER:

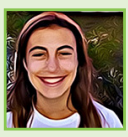

\section{GWEN}

AGE: 13

\section{SALINITY}

The amount of salt in water. Freshwater has low salinity, and sea water has high salinity.
Estuaries are places on the earth where rivers meet oceans. When rain and snowmelt drain off the land, the fresh water collects in streams and rivers and eventually makes its way to the ocean. At the same time, the ocean has tides that push salty water upstream into the rivers. This place, where rivers and oceans mix, is called an estuary. Estuaries contain many kinds of habitats that are home to plants and animals. Many people work and live in estuaries. In this article, I describe what makes estuaries interesting and important to plants, animals, and people. I also explain how these important areas are under threat from certain human activities.

\section{WHAT IS AN ESTUARY?}

An estuary is a place where streams and rivers mix with the ocean (Figures $1 A, B)$. An estuary is special because it is partly a river, partly an ocean, but also a place where these two kinds of water meet and mix. In most estuaries around the world, there is a salinity gradient as you move oceanward, with saltier water near the ocean and freshwater in the upper reaches, near rivers. An estuary has tides like the ocean, so the height of the water changes every few hours due to the 
Figure 1

(A) Aerial photograph of the Murry River Estuary, Australia. This is a relatively undisturbed estuary, with some agriculture in the upper left of the photo (Permission for use granted via Creative Commons. Image credit: https:// freeaussiestock. com/free/

Queensland/slides/ st_helens_beach_ estuary.htm). (B) Satellite image of the Marin-Sonoma Counties Bay in California, showing extensive development within the San

Francisco Estuary (roads and buildings are white or gray). This is an urbanized estuary, with much pavement and urban hardscape (Permission for use granted to the author. Image credit: http:// www.krisweb.com/ watershd/ sanrafael_nasa.jpg).

MARSH

A tract of low, wet land, often treeless and periodically flooded, generally characterized by the growth of grasses, sedges, cattails, and rushes.

\section{RUNOFF}

Something that drains or flows off, as rain that flows off from the land in streams.

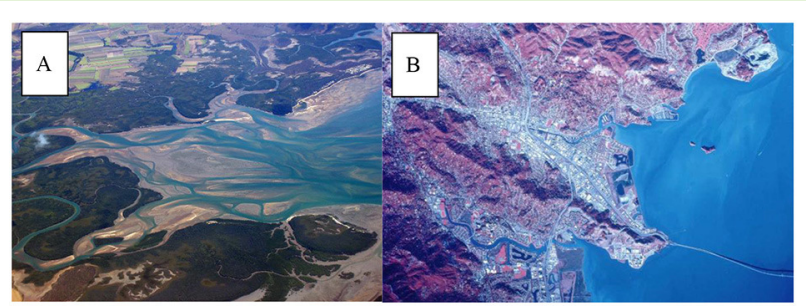

Figure 1

gravitational pull of the moon as it circles the earth. Estuaries have rivers and creeks running through them too, so their water levels also change depending on how much rain and snow drains down to them. Estuaries have shallow parts and deep parts, muddy parts and clear parts. There are freshwater edges that have marsh plants, and very deep, dark, saltwater channels where sunlight does not reach the bottom. There is no place on Earth that has as many different habitats so close together as we find in an estuary.

Estuaries have also included people for a very long time, because humans like to fish, swim, and play in them. Many people live near or in an estuary, and estuaries are important places to store boats and goods moved between countries across the sea. For example, the Nile Delta estuary was likely populated by almost 2 million people before 3,000 B.C., and it is home to 39 million people today.

In this article, I describe several important facts about estuaries [1]. I think estuaries are special because of the different features we find there: physical, chemical, biological, and geological. An estuary is part stream, part lake, and part beach; it is partly fresh water and partly salty; it is partly land and partly water. An estuary is all these things all at once!

\section{WHERE ARE ESTUARIES?}

Estuaries are commonly found on coasts. Water draining off the land finds its way down to the sea, usually flowing in large rivers. While there are small estuaries, most of the world's important estuaries are big, and are found at the end of long, large rivers like the Mississippi River in North America, the Nile River in Africa and the Middle East, and the Amazon River in South America. I live near the San Francisco Estuary in California, where one of the largest rivers on the west coast of the United States, the Sacramento river, washes into the Pacific Ocean. The San Francisco Estuary receives river flow from almost half of the state of California, including snowmelt and runoff from the Sierra mountains, $100 \mathrm{~km}$ or more from the Pacific Ocean (Figure 2). 
Figure 2

Map of the San

Francisco Estuary and

Bay Watersheds

(darker-colored areas

highlighted in black)

from the

Sacramento-San

Joaquin Delta to the

Pacific Ocean near San

Francisco, California

(Permission for use

granted to the author.

Image credit: http://

www.cemar.org/

steelhead_sfew.html).

\section{FLOODPLAIN}

A nearly flat plain along the course of a stream or river that is naturally subject to flooding.

\section{BRACKISH}

Slightly salty.

\section{MIGRATION \\ CORRIDOR}

Routes followed by animals, birds, or fish when traveling between different habitats, as in salmon moving from the ocean to rivers to spawn.

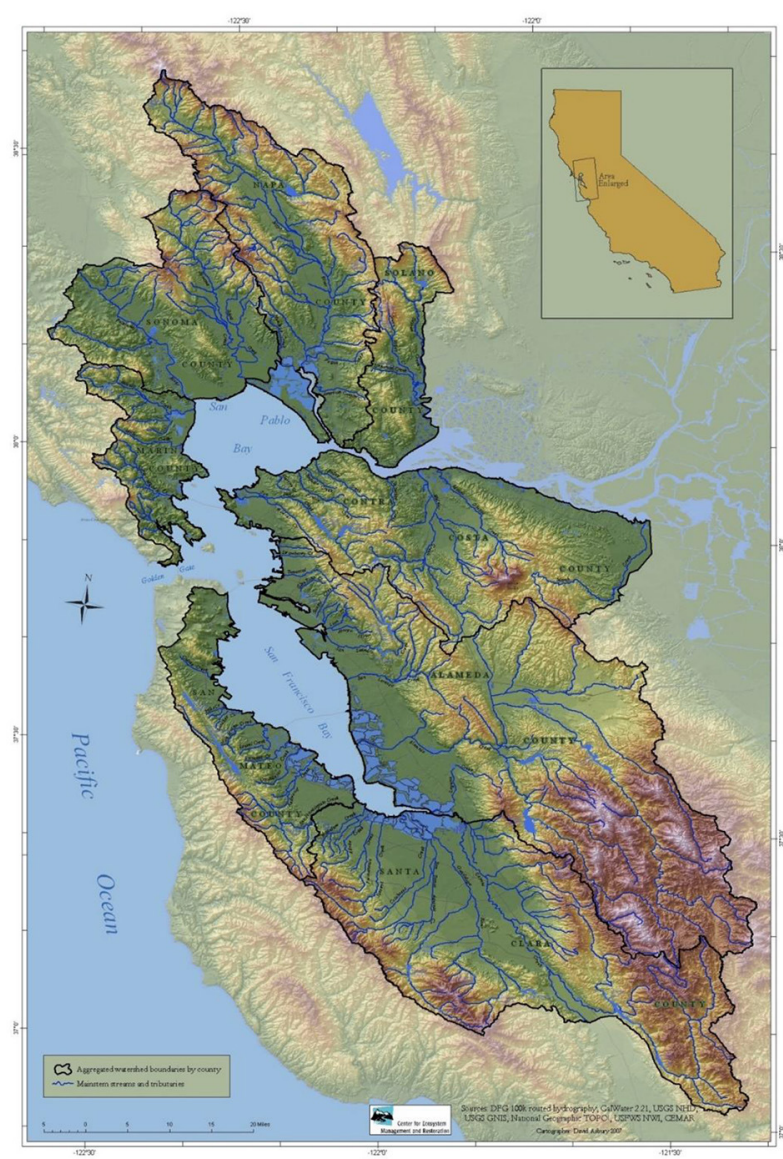

Figure 2

\section{WHAT PLANTS AND ANIMALS LIVE IN ESTUARIES?}

Estuaries have habitats like those of oceans, rivers, floodplains, and lakes. Many estuaries also experience dry seasons with little rain or snow, and wet seasons with flooding and lots of mountain snowmelt and runoff. Many species can find habitats to their liking in estuaries. Therefore, estuaries are home to more species of plants and animals than almost any other place on Earth. For example, there are more than 500 species of fish and wildlife in the San Francisco Estuary! There are marine creatures that like to live in estuaries, and plenty of plants and animals from freshwater places also find homes in estuaries, as long as conditions do not get too salty for too long. Many organisms in estuaries are adapted to brackish water, like species of crabs, insects, fish, birds, snakes, and even otters. These organisms use the mixing zone of estuaries, where salt and fresh water come together, to raise their young or as a migration corridor. Well-known migratory species, like salmon and sturgeon, spend some time during their lives in estuaries, as they move from the coast or the ocean to the interior rivers and back again. Ducks and many other birds find resting places in estuaries during their long-distance migrations. So, it is easy to understand how so many plants and animals can be found in estuaries - there are many different habitats to fill. 
ECOSYSTEM

SERVICES

The important benefits for people that arise from healthily functioning ecosystems, notably production of oxygen, creation of soil, and water purification.

\section{INFILLING}

To fill in with soil or sediment, as in the placement of soil to prepare for the construction of buildings.

\section{DO PEOPLE HAVE AN EFFECT ON ESTUARIES?}

People find it satisfying to live in or visit estuaries; swimming, boating, hunting, or fishing in an environment that is sometimes like the ocean and sometimes like the river. People have discovered they can use estuaries as places to build harbors and factories and still be near transportation services and nice places to live and relax. Put a different way, estuaries are places where we can find many ecosystem services, which are benefits that an ecosystem provides [2]. Easy access to drinking water, plentiful fish and seafood for eating and selling, large quantities of water to dilute pollution from factories or sewers, and readily available open land near the ocean-these are all reasons why people are drawn to work and live in estuaries. For example, owing to the nice weather and pleasant scenery near the coast, and because of the variety of ecosystem services available, almost 8 million people lived in or near San Francisco Estuary's shorelines and coasts in 2019 [3].

People have been congregating in and interacting with estuaries for thousands of years [4]. Due to human activities, changes occur to river flow, tides, and the plants and animals that live in estuaries. Pollution accumulates, and huge quantities of water are captured and pumped elsewhere for drinking, agriculture, industry, and other uses. Civilizations have profited greatly from estuaries for thousands of years, and the health of our estuaries is connected to the health and wealth of the people who live, work, and play there.

Some people (like me!) choose to study estuaries to understand how they work. As scientists have noticed the negative effects that humans can have on estuaries, people have also decided to protect the estuarine wildlife and the habitats, by creating parks or reserves where estuaries can remain natural. Often, however, humans contribute to the degradation of estuaries by ignoring their value to society, and by doing things that contribute to the destruction of estuaries, like infilling or draining, or by building urban areas, roads, and ports.

\section{WHAT WILL HAPPEN TO ESTUARIES IN THE FUTURE?}

Global climate change and sea-level rise are affecting estuaries worldwide [5]. Ocean circulation and rainfall patterns are changing, land is sinking, and floods and droughts are more common in and around estuaries. Temperatures in many places are getting warmer over time, and normal weather is being replaced by unusually strong storms or changes in their frequency. All of these things imperil the habitats and ecosystem services provided by estuaries all over the world. In the San Francisco Estuary for example, many wetlands are getting squeezed between the rising ocean and the cities we have built right up to the edges of the estuary (Figure 3). The upper edges of 
Figure 3

(A) Normally, as sea level rises, wetlands naturally progress higher onto the surrounding shore. (B) When people build seawalls and buildings near the shore, this creates barriers to the tides, and the marsh can no longer move inland. This is called coastal squeeze. (C) Coastal squeeze occurs naturally too, where rocks or steep slopes prevent landward movement of marshes (Permission for use granted to the author by the Ocean Wise Conservation Association. Image credit: https:// oceanwatch.ca/ howesound/wpcontent/uploads/ sites/2/2016/11/ diagram-coastalsqueeze-BRANDED. png).

\section{Coastal squeeze}
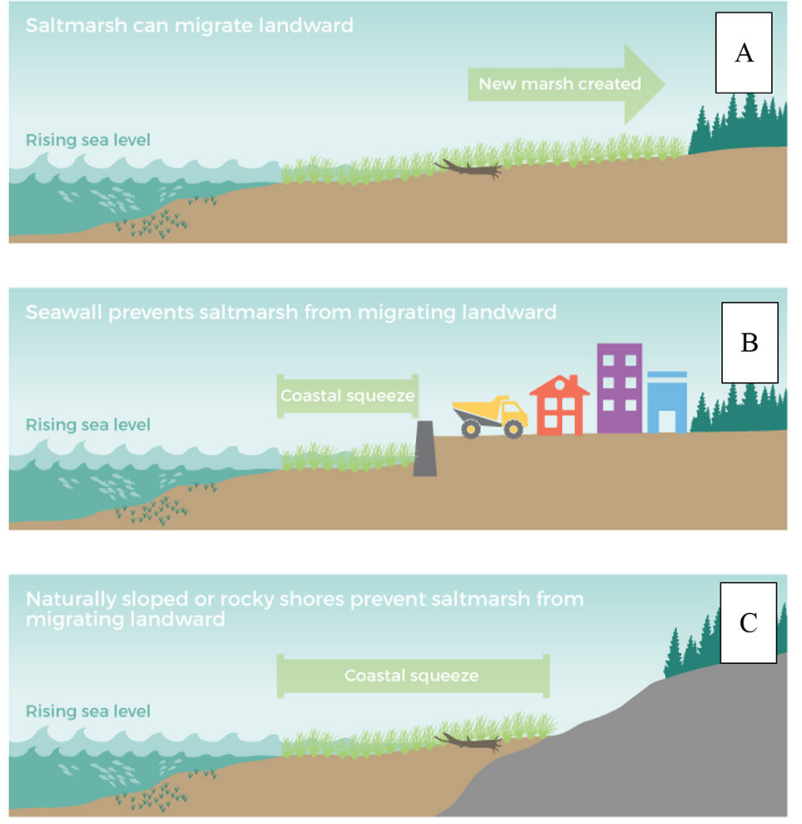

OCEANWATCLH

Figure 3

estuaries are at risk because the natural upward movement of estuaries is commonly blocked by manmade structures such as paved areas, buildings, roads, or railways. San Francisco Estuary's marshes are at risk of being flooded and drowned because they cannot move upward or landward as the sea level rises, the way they could before roads and buildings blocked their path. If these estuary habitats disappear, birds, fish, and crabs will have fewer places to live and they might be exposed to more pollution. If our cities get flooded more often, many businesses and people may have to move to places that are higher and drier, or they may have to pay more to repair damage caused by rising ocean tides.

There will always be an estuary between California's rivers and the Pacific Ocean, but where that estuary is or what it looks like-physically, chemically, biologically, and geologically-will change rapidly over the next 5 to 50 years. This is also true for other estuaries all over the world. How governments decide to regulate and protect estuarine environments will have ripple effects on fisheries and wildlife habitats far into the future. The health of our estuaries-and human health and wealth-lies in the balance we achieve between industry and commerce and the need to preserve natural open spaces, like estuaries. What we decide we want estuaries to look like in the future will be one legacy of our human history. You can choose to be part of building that legacy by learning about and talking with your friends about what makes estuaries so special and useful. 


\section{REFERENCES}

1. U.S. Environmental Protection Agency, National Estuary Program. 2020. Basic Information About Estuaries. Available online at: https://www.epa.gov/nep/ basic-information-about-estuaries (accessed September 23, 2020).

2. CGIAR. 2020. Research Program on Water, Land, and Ecosystems. Available online at: https://wle.cgiar.org/topics/ecosystem-services (accessed September 23, 2020)

3. U.S. Census Bureau. 2019. Bay Area Population Growth. Available online at: https://www.kqed.org/news/11741275/map-the-bay-area-leads-californiain-population-growth (accessed September 23, 2020).

4. Lotze, H. K. 2010. Historical reconstruction of human-induced changes in U.S. estuaries. Oceanogr. Mar. Biol. Ann. Rev. 48:267-338. doi: 10.1201/EBK143982 1169-c5

5. National Oceanographic and Atmospheric Administration. 2020. ClimateWatch Magazine. Available online at: https://www.climate.gov/news-features/under standing-climate/climate-change-global-sea-level (accessed September 23, 2020).

SUBMITTED: 28 September 2020; ACCEPTED: 11 June 2021;

PUBLISHED ONLINE: 12 July 2021.

EDITED BY: Peggy W. Lehman, California Department of Water Resources, United States

CITATION: Culberson SD (2021) Estuaries, Human Beings, and the Future. Front. Young Minds 9:611371. doi: 10.3389/frym.2021.611371

CONFLICT OF INTEREST: The author declares that the research was conducted in the absence of any commercial or financial relationships that could be construed as a potential conflict of interest.

COPYRIGHT @ 2021 Culberson. This is an open-access article distributed under the terms of the Creative Commons Attribution License (CC BY). The use, distribution or reproduction in other forums is permitted, provided the original author(s) and the copyright owner(s) are credited and that the original publication in this journal is cited, in accordance with accepted academic practice. No use, distribution or reproduction is permitted which does not comply with these terms.

\section{YOUNG REVIEWER}

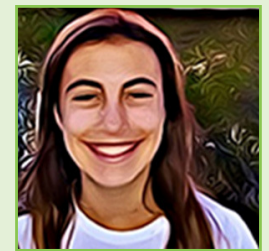

\section{GWEN, AGE: 13}

$\mathrm{Hi}$, my name is Gwen, I live in the U.S. and play piano and volleyball. I am in 8th grade, and my favorite subjects are science, math, art, and Spanish. I love to read, particularly Sci-Fi novels and series (I am also a huge fan of Harry Potter). I am very excited to be working with Frontiers for Young Minds! 


\section{AUTHOR}

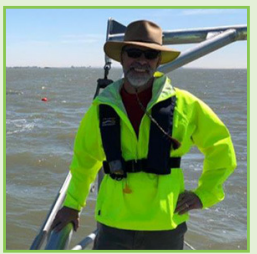

\section{STEVEN D. CULBERSON}

Dr. Steven Culberson is an estuarine ecologist. His interests in water, habitats, and organisms led him to study how the physical and biological worlds come together to form ecosystems. *steve.culberson@ adeltacouncil.ca.gov 